\title{
UPAYA MENINGKATKAN HASIL BELAJAR SISWA MELALUI PENERAPAN PENDEKATAN PENDIDIKAN MATEMATIKA REALISTIK (PMR)
}

\author{
Dona Setiani ${ }^{1}$, Hanifah ${ }^{2}$, Effie Efrida Muchlis ${ }^{3}$ \\ ${ }^{1,3}$ Program Studi Pendidikan Matematika JPMIPA FKIP Universitas Bengkulu \\ ${ }^{2}$ Program Studi S-2 Pendidikan Dasar FKIP Universitas Bengkulu \\ 1'donasetiani19@gmail.com, ${ }^{2}$ ifahzen@gmail.com, ${ }^{3}$ effie_efrida@yahoo.com
}

\begin{abstract}
Abstrak
Penelitian ini bertujuan untuk mengetahui cara menerapkan pendekatan Pendidikan Matematika Realistik (PMR) sehingga dapat meningkatkan aktivitas dan hasil belajar siswa pada pokok bahasan bangun ruang sisi datar. Jenis penelitian ini adalah Penelitian Tindakan Kelas (PTK). Subjek Penelitian ini adalah 30 siswa kelas VIIIA SMPN 1 Pondok Kelapa semester genap tahun ajaran 2016/2017. Instrumen yang digunakan adalah lembar observasi aktivitas dan tes hasil belajar siswa. Hasil penelitian menunjukkan terjadi peningkatan aktivitas belajar siswa yang dilakukan dengan cara membentuk kelompok diskusi yang heterogen, menggunakan alat peraga dalam mengkonstruksi ide matematika, membimbing siswa dalam kegiatan kelompok, dan memberikan motivasi dan apresiasi berupa pujian. Hasil belajar siswa juga dapat ditingkatkan dengan cara mengingatkan pada materi pertemuan sebelumnya, mengaitkan manfaat belajar materi melalui masalah kontekstual, memberikan soal latihan, membimbing dalam menemukan konsep melalui LKPD berbasis PMR, mengingatkan untuk membaca materi pertemuan selanjutnya.
\end{abstract}

Kata kunci: Aktivitas Belajar; Hasil Belajar; PMR.

\begin{abstract}
This study aims to find out how to apply the approach of Realistic Mathematics Education (RME) that improves student activities and learning outcomes on the topics of flat side solids. This type of research is Classroom Action Research (CAR). The subject of this research is 30 students of class VIIIA SMPN 1 Pondok Kelapa even semester of 2016/2017 academic year. The instruments used are activity observation sheets and test result of student learning. The results showed that there was an improvement in the student's learning activities by forming heterogeneous discussion groups, using visual aids in constructing mathematical ideas, guiding them to take on the task of group activities, and providing motivation and appreciation in the form of praise. Student learning outcomes can also be improved by reminding the material of previous meetings, linking the benefits of learning materials through contextual issues, giving practice questions, guiding in finding concepts through PMR-based $L K P D$ and reminding them to read the next meeting material.
\end{abstract}

Keywords: Learning Activity; Learning outcomes; RME.

\section{PENDAHULUAN}

Pembelajaran matematika di sekolah hendaknya menanamkan kebermaknaan suatu pembelajaran kepada siswa sebagaimana perubahan mindset pada kurikulum 2013. Berdasarkan hasil observasi dan wawancara dengan guru matematika dan siswa di SMPN 1 Pondok Kelapa diketahui bahwa masih terdapat siswa yang memperoleh hasil belajar dibawah
Kriteria Ketuntasan Minimal (KKM), yaitu 65. Pembelajaran matematika belum dikaitkan dengan konteks dunia nyata dan penggunaan alat peraga dalam pembelajaran belum maksimal. Selain itu, siswa juga belum dilibatkan langsung dalam mengkonstruksi sendiri ide matematika, yang menyebabkan pembelajaran berlangsung satu arah (terpusat pada guru). Kelas VIIIA merupakan kelas dengan nilai rata-rata siswanya pada ulangan 
semester ganjil tahun ajaran 2016/2017 yang tergolong rendah, yaitu 52 dengan ketuntasan belajar klasikal 13,33\%.

Oleh sebab itu, perlu diterapkan pendekatan pembelajaran matematika yang memanfaatkan lingkungan sebagai sumber belajar serta menekankan kebermaknaan ilmu pengetahuan kepada peserta didik. Pendekatan pembelajaran yang dipandang sesuai untuk kondisi diatas adalah pendekatan Pendidikan Matematika Realistik (PMR). Pendekatan PMR diartikan oleh Wijaya (2012 : 3) sebagai suatu pendekatan pembelajaran yang menekankan pada penggunaan konteks dan kebermaknaan ilmu pengetahuan. Materi bangun ruang sisi datar yang pada hakikatnya berkaitan dengan aplikasi dalam kehidupan sehari-hari, dalam pembelajarannya memerlukan bantuan model untuk memudahkan memahaminya. Hal ini dipandang sesuai apabila diajarkan melalui pendekatan PMR. Penerapan pendekatan pembelajaran ini diharapkan dapat mengubah pemikiran siswa tentang matematika dari pembelajaran yang mekanistis menjadi humanistik.

Berdasarkan latar belakang masalah, maka rumusan masalah dari penelitian ini yakni :

Bagaimana penerapan pendekatan

Pendidikan Matematika Realsitik (PMR) sehingga dapat meningkatkan hasil belajar siswa pada pokok bahasan bangun ruang sisi datar di kelas VIIIA SMPN 1 Pondok Kelapa?

Adapun tujuan dari penelitian ini yakni : Untuk mengetahui cara menerapkan pendekatan Pendidikan Matematika Realistik (PMR) sehingga dapat meningkatkan hasil belajar siswa pada pokok bahasan bangun ruang sisi datar di kelas VIIIA SMPN 1 Pondok Kelapa.

\section{A. Pendekatan Pendidikan Matematika Realistik (PMR)}

Pendidikan Matematika Realistik menurut Zulkardi (Fathurrohman, 2015 : 189) merupakan suatu pendekatan pembelajaran matematika yang menekankan penggunaan situasi dunia nyata dan pengalaman siswa sebagai titik tolak belajar matematika. Dalam pembelajaran ini siswa diajak untuk membentuk pengetahuan sendiri berdasarkan pengalaman yang telah mereka dapatkan atau alami sebelumnya. Penggunaan konteks dalam PMR harus bisa dibayangkan oleh siswa dan memunculkan proses matematisasi. Matematisasi digambarkan oleh Gravemeijer (1994 : 94) sebagai proses penemuan kembali (reinvention) seperti pada gambar 1 berikut.

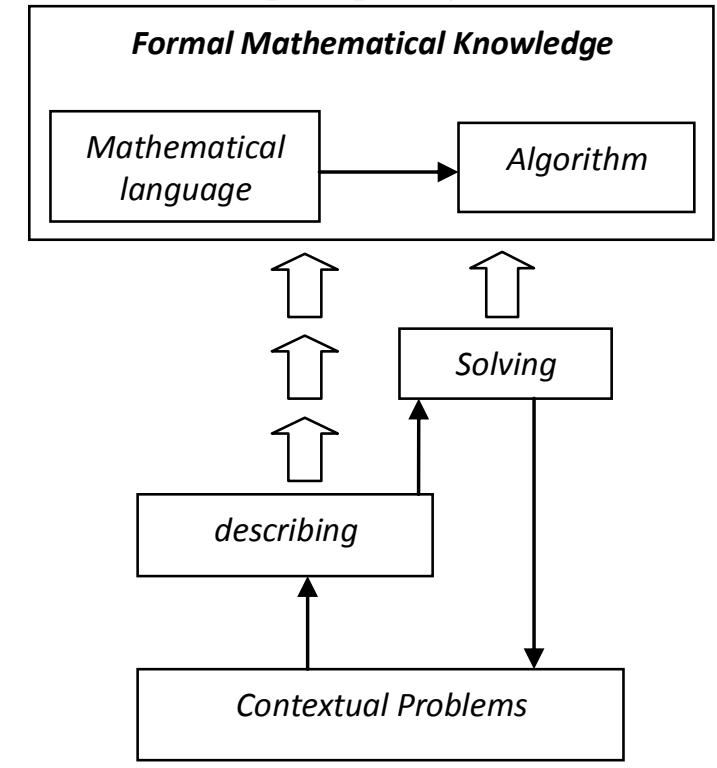

Proses matematisasi horizontal dimulai dari masalah kontekstual dan diuraikan dengan bahasa dan simbol yang dibuat sendiri, kemudian baru menyelesaikan soal tersebut. Sedangkan Matematisasi vertikal merupakan proses pengorganisasian kembali dengan menggunakan matematika itu sendiri. Menurut Gravemeijer, matematisasi vertikal ini dapat juga dimulai dari masalah kontekstual, tetapi dalam jangka panjang dapat disusun prosedur tertentu (algoritma) yang dapat digunakan untuk menyelesaikan soal-soal sejenis secara langsung, tanpa menggunakan bantuan konteks.

Pendekatan PMR memiliki 5 karakteristik menurut Treffers (Wijaya, 2012 : 21-23), yaitu penggunaan konteks (titik awal pembelajaran matematika), penggunaan model untuk matematisasi progresif (jembatan pengetahuan dari tingkat konkrit ke formal), pemanfaatan hasil konstruksi siswa (landasan pengembangan konsep matematika), interaktivitas (mengkomunikasikan hasil kerja dan gagasan), dan keterkaitan (mengenalkan dan membangun lebih dari satu konsep matematika). Selain itu PMR juga memiliki tiga prinsip menurut Gravemeijer (1994 90), yaitu guided re- 
invention and progressive mathematizing (menemukan kembali secara terbimbing dan matematisasi progresif) dimana siswa diberi kebebasan melakukan matematisasi dengan bimbingan guru, didactical phenomenology (fenomena didaktif) dimana siswa konteks yang disajikan sebagai titik tolak dalam proses pematematikaan dan mempunyai aplikasi dalam pengajaran, dan self-delevoped models (membangun sendiri model) dimana siswa membangun sendiri model dengan strategi yang bervariasi.

Adapun langkah-langkah pembelajaran dengan pendekatan PMR menurut Shoimin (2014 : 150), yaitu :

1. Memahami Masalah Kontekstual

Guru memberikan masalah (soal) kontekstual dan siswa diminta untuk memahami masalah tersebut.

2. Menyelesaikan Masalah Kontekstual

Siswa diminta untuk menyelesaikan masalah kontekstual pada LKPD dengan caranya sendiri. Guru memberikan pertanyaan-pertanyaan penuntun untuk mengarahkan siswa memperoleh penyelesaian soal.

3. Membandingkan dan Mendiskusikan Jawaban

Siswa diminta untuk membandingkan dan mendiskusikan jawaban mereka dalam kelompok kecil melalui pemanfaatan hasil konstruksi siswa, lalu dibandingkan pada diskusi kelas yang dipimpin oleh guru.

4. Menarik Kesimpulan

Guru mengarahkan siswa untuk menarik kesimpulan tentang konsep, definisi, teorema, prinsip, atau pun prosedur matematika yang terkait dengan masalah kontekstual yang baru diselesaikan.

Keempat langkah diatas tidak terlepas dari penerapan karakteristik dan prinsip pendekatan PMR yang saling berkaitan.

\section{B. Hasil Belajar}

Suatu kegiatan belajar mengajar akan menghasilkan output berupa hasil belajar. Menurut Abdurrahman (Jihad dan Haris, 2008 : 14), hasil belajar adalah kemampuan yang diperoleh anak setelah melalui kegiatan belajar. Siswa yang berhasil dalam belajar adalah yang berhasil mecapai tujuan-tujuan pembelajaran atau tujuan instruksional.

Benjamin S. Bloom (Sudijono, 2011 : 49) menyatakan bahwa taksonomi (pengelompokan) tujuan pendidikan harus senantiasa mengacu kepada tiga jenis ranah, yaitu :

1. Ranah Kognitif, yang terdiri atas enam jenjang menurut Bloom yakni: (a) pengetahuan/hafalan/ingatan (knowledge), (b) pemahaman (comprehension), (c) penerapan (application), (d) analisis (analysis), (e) sintesis (synthesis), dan (f) penilaian (evaluation).

2. Ranah Afektif, yang terdiri atas lima jenjang, yakni: (a) menerima atau memperhatikan (receiving), (b) menanggapi (responding), (c) menilai atau menghargai (valuing), (d) mengorganisasikan (organization), (e) karakterisasi dengan suatu nilai atau komplek nilai (characterization by a value or value complex).

3. Ranah Psikomotor, yang terdiri atas lima jenjang, yakni : (a) peniruan (imitation), (b) manipulasi (manipulation), (c) keseksamaan (precision), (d) artikulasi (articulation),

(e) naturalisasi (naturalization).

Pada penelitian ini, hasil belajar siswa lebih difokuskan pada aspek kognitif jenjang pengetahuan, pemahaman, dan penerapan.

\section{METODE}

Jenis penelitian yang dilakukan adalah penelitian tindakan kelas (PTK). Kunandar (2013: 44-45) berpendapat bahwa PTK merupakan suatu penelitian tindakan yang dilakukan oleh guru (peneliti) di kelasnya atau bersama-sama dengan orang lain dengan jalan merancang, melaksanakan dan merefleksikan tindakan secara kolaboratif dan partisipatif yang bertujuan untuk memperbaiki atau meningkatkan mutu proses pembelajaran di kelasnya melalui suatu tindakan tertentu dalam suatu siklus. PTk dilakukan dengan beberapa tahapan menurut Trianto (2011 : 35)., yaitu (1) penyusunan rencana (planning), melaksanakan tindakan (acting), 
pengamatan (observating), (4) refleksi (reflecting).

Penelitian ini dilaksanakan di kelas VIIIA SMPN 1 Pondok Kelapa semester genap tahun ajaran 2016/2017 yang berlokasi di Jalan Raya Pasar Pedati, Kecamatan Pondok Kelapa, Kabupaten Bengkulu Tengah. Penentuan waktu penelitian mengacu pada kalender akademik sekolah. Subjek penelitian ini adalah seluruh siswa kelas VIIIA yang berjumlah 30 siswa, terdiri atas 3 siswa laki-laki dan 27 siswa perempuan.

Instrumen yang digunakan dalam penelitian ini adalah lembar tes hasil belajar (THB) siswa yang dilakukan setiap akhir siklus. Data yang diperoleh dianalisis secara deskriptif. Nilai tes hasil belajar diperoleh dari setiap siklus untuk mengetahui nilai rata-rata hasil belajar dan persentase ketuntasan belajar. Rumus yang digunakan untuk menghitung nilai rata-rata hasil belajar yaitu :

$$
\begin{aligned}
& \bar{X}=\frac{\sum X}{\sum N} \\
& \sum X=\text { Jumlah semua nilai siswa } \\
& \sum N=\text { Jumlah siswa }
\end{aligned}
$$$$
\text { (Daryanto, } 2014 \text { : 191) }
$$

Berdasarkan kurikulum 2013 di SMP Negeri 1 Pondok Kelapa menyatakan ketuntasan belajar untuk (a) individu: jika siswa mendapat nilai $\geq 65$, (b) klasikal: jika $75 \%$ siswa mendapat nilai $\geq 65$. Persentase ketuntasan belajar klasikal dihitung dengan menggunakan persamaan:

\section{$\boldsymbol{P}$ \\ $=\frac{\sum \text { Siswa yang tuntas belajar }}{\sum \text { Seluruh siswa }} \times 100 \%$}

Keterangan : $P=$ persentase ketuntasan belajar klasikal

(Daryanto, 2014 : 192)

Siklus penelitian ini akan dihentikan jika kriteria keberhasilan tindakan telah tercapai. Indikator keberhasilan tindakan dalam penelitian ini adalah :

1. Aktivitas belajar siswa dalam pelaksanaan pembelajaran minimal berada pada kriteria baik yaitu memenuhi interval $34 \leq x \leq 41$
2. Nilai rata-rata siswa setiap siklus meningkat.

3. Ketuntasan belajar tercapai apabila siswa mendapat nilai $\geq$ KKM yaitu 65 . Berdasarkan ketuntasan belajar klasikal, dianggap tuntas jika $75 \%$ siswa mendapat nilai $\geq 65$.

\section{HASIL DAN PEMBAHASAN}

Penelitian ini dilaksanakan dalam 3 siklus. Pada siklus I, siswa masih bingung dan belum terbiasa dalam pembelajaran menggunakan pendekatan PMR. Pada tahap memahami masalah kontekstual, siswa sudah mengenali dan dapat menyebutkan benda-benda berbentuk bangun ruang sisi datar di sekitar tetapi belum tahu bagaimana menentukan luas permukaannya.

Pada tahap menyelesaikan masalah kontekstual, siswa kurang disiplin dan masih bingung ketika menggunakan model untuk matematisasi progresif. Siswa belum dapat membangun sendiri model ke dalam bentuk simbol matematika, sehingga guru memberikan petunjuk dan bimbingan seperlunya. Umumnya siswa belum membaca dengan teliti langkahlangkah pada LKPD. Namun, rata-rata siswa sudah dapat memanfaatkan keterkaitan antara materi yang sedang dipelajari dengan materi lain yang berhubungan dengan materi tersebut walaupun masih perlu bimbingan dari guru. Diskusi kelompok siswa belum seluruhnya aktif dan hanya siswa-siswa tertentu saja yang mengerjakan LKPD. Siswa masih kesulitan dalam menuliskan jawaban dari hasil matematisasi kelompoknya pada LKPD.

Hal ini berdampak pada aktivitas siswa pada tahap membandingkan dan mendiskusikan jawaban. Siswa masih kaku dan kurang aktif dalam diskusi kelas, masih sedikit siswa yang bertanya atau menanggapi presentasi kelompok penyaji. Pada tahap menarik kesimpulan siswa masih perlu dibimbing dalam menyimpulkan tentang konsep dari materi yang dipelajari.

Pada siklus II, guru mengubah susunan kelompok berdasarkan nilai THB siklus I, menyusun LKPD dengan bahasa yang lebih sederhana dan diperjelas, melakukan bimbingan lebih kepada siswa yang mengalami kesulitan berupa pertanyaan-pertanyaan 
penuntun, meminta siswa untuk lebih disiplin terhadap waktu, menuntun siswa untuk aktif dalam diskusi kelompok maupun diskusi kelas, dengan menyampaikan minimal 1 pertanyaan/tanggapan untuk setiap kelompoknya. Siswa sudah mulai terbiasa dengan pembelajaran menggunakan pendekatan PMR. Namun, masih terdapat siswa yang bingung menggunakan alat peraga saat kegiatan menyelesaikan masalah dan mengaitkan nya dengan pertanyaan-pertanyaan pada LKPD. Ketika kelompok penyaji presentasi, siswa ada yang ribut dan kurang memperhatikan. Keaktifan siswa dalam diskusi kelompok dan diskusi kelas juga perlu ditingkatkan lagi.

Tindakan yang dilakukan pada siklus III mengacu pada hasil refleksi siklus II yaitu guru membagi ulang kelompok diskusi siswa berdasarkan tes hasil belajar siklus II, lebih membimbing siswa dalam menggunakan alat peraga dengan memberikan petunjuk-petunjuk, mengarahkan siswa untuk menyampaikan minimal 2 pertanyaan/ tanggapan perkelompok, dan menegur siswa yang ribut atau sibuk mengobrol bukan tentang pelajaran.

Berikut ini adalah rekapitulasi perhitungan hasil belajar siswa setiap siklusnya :

Tabel 1. Hasil Belajar Siswa Setiap Siklus

\begin{tabular}{|c|c|c|c|}
\hline Siklus & $\begin{array}{c}\text { Nilai } \\
\text { Rata- } \\
\text { Rata }\end{array}$ & $\begin{array}{c}\text { Ketuntasan } \\
\text { Belajar } \\
\text { Klasikal }\end{array}$ & Keterangan \\
\hline I & 60,43 & $33,33 \%$ & $\begin{array}{c}\text { Belum } \\
\text { Tuntas }\end{array}$ \\
\hline II & 75,77 & $66,67 \%$ & $\begin{array}{c}\text { Belum } \\
\text { Tuntas }\end{array}$ \\
\hline III & 85,83 & $86,67 \%$ & Tuntas \\
\hline
\end{tabular}

Berdasarkan tabel 1, pada siklus I nilai rata-rata dan ketuntasan belajar klasikal siswa masih rendah. Berdasarkan pengamatan guru terhadap hasil belajar siswa, siswa yang mencapai KKM adalah 10 orang dan yang tidak mencapai KKM yaitu sebanyak 20 orang. Pada siklus I, siswa sudah tahu mengenai konsep mendapatkan rumus luas permukaan bangun ruang sisi datar dan mengingat materi yang telah dipelajari, tetapi ketika dihadapkan pada soal-soal yang merupakan penerapan dari konsep tersebut, siswa masih kesulitan dalam menganalisis untuk mendapatkan solusi penyelesaian soal. Sehingga pada siklus I belum mencapai kriteria tuntas, yaitu nilai ratarata siswa 60,43 dan ketuntasan belajar klasikal hanya 33,33 \%. Oleh karena itu, guru memberikan soal latihan lebih banyak dan membahasnya bersama-sama dengan siswa dan mengingatkan pada materi sebelumnya sebelum masuk pada materi baru.

Pada siklus II, guru menambah jumlah pertemuan agar bisa membahas soal-soal latihan lebih intensif. Hal ini menyebabkan hasil belajar siswa mengalami peningkatan, baik nilai rata-rata maupun ketuntasan belajar klasikal. Namun, ketuntasan belajar klasikal siswa belum mencapai indikator keberhasilan, yaitu masih $66,67 \%$. Berdasarkan pengamatan terhadap THB siklus II, siswa sudah dapat menerapkan pengetahuan yang dimiliki dalam menghitung volume bangun ruang sisi datar. Namun, beberapa siswa masih salah dalam menggunakan satuan volume bangun ruang sisi datar. Selain itu, masih terdapat siswa yang lupa terhadap materi yang berkaitan untuk menyelesaikan soal tentang volume bangun ruang sisi datar, seperti teorema pythagoras. Hal ini menyebabkan jawaban akhir siswa juga ikut salah. Oleh sebab itu, ketika selesai tes siklus II guru mengulas sekilas kembali tentang materi teorema pythagoras dan penggunaan satuan.

Pada siklus III, hasil belajar siswa mengalami peningkatan, yaitu dengan nilai rata-rata 85,83 dan ketuntasan belajar klasikal $86,67 \%$. Hal menunjukkan bahwa hasil belajar siswa telah mencapai kriteria tuntas sesuai dengan indikator keberhasilan tindakan. Oleh sebab itu, penelitian dihentikan pada siklus III. Adapun peningkatan ketuntasan belajar klaskal siswa dapat dilihat pada gambar 2 berikut :

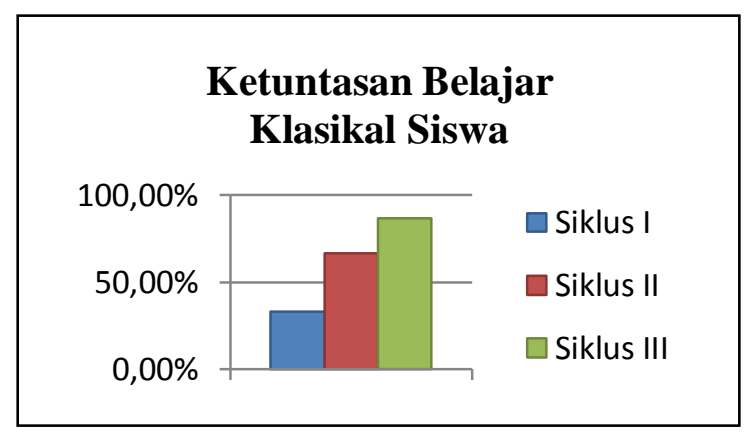

Gambar 2. Ketuntasan Belajar Klasikal Siswa Pada Setiap Siklus 
Peningkatan juga terjadi pada nilai individu siswa setiap siklusnya. Siswa yang mempunyai nilai yang selalu meningkat ratarata adalah siswa yang selalu hadir dan aktif dalam kegiatan pembelajaran setiap siklusnya. Berdasarkan nilai tes hasil belajar siswa pada setiap siklus, perkembangan nilai hasil belajar siswa dapat dilihat pada grafik berikut ini :

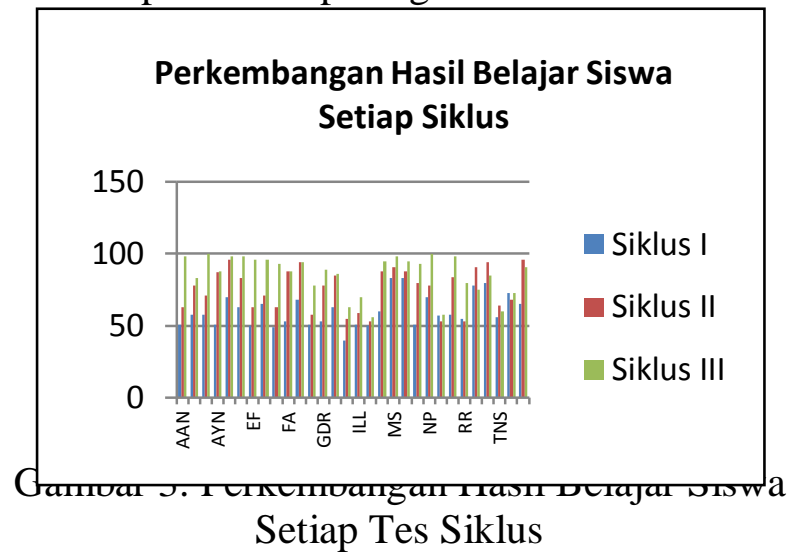

Dari gambar 3 diatas, dapat dilihat bahwa perkembangan nilai tes hasil belajar siswa tidak selalu meningkat pada setiap siklusnya. Jumlah siswa yang nilai tes hasil belajarnya selalu mengalami peningkatan pada setiap siklusnya adalah 23 siswa, artinya persentasi nilai siswa yang selalu mengalami peningkatan adalah $76,67 \%$. Sedangkan 7 siswa atau 23,33\% mengalami turun naik nilai pada setiap tes siklusnya.

Berdasarkan hasil pengamatan peneliti terhadap nilai tes siklus siswa pada ketiga siklus tersebut, terdapat 4 siswa atau 13,33\% yang tidak pernah mencapai nilai $\geq 65$ (KKM). Beberapa faktor yang menyebabkan 4 siswa tersebut tidak pernah mencapai nilai $\geq 65$ yaitu siswa tidak mengikuti secara penuh kegiatan pembelajaran, siswa kurang menyiapkan diri untuk menghadapi tes siklus, siswa kurang memperhatikan pelajaran dan penjelasan dari guru saat proses pembelajaran berlangsung, siswa malu untuk bertanya kepada guru maupun teman ketika tidak memahami pelajaran, dan kurangnya ketelitian siswa saat mengerjakan soal tes. Akan tetapi, secara umum hasil belajar siswa kelas VIIIA mengalami peningkatan nilai rata-rata maupun ketuntasan belajar klasikal pada setiap siklusnya.

\section{PENUTUP}

Simpulan

Penerapan pendekatan Pendidikan Matematika Realistik (PMR) dapat meningkatkan hasil belajar siswa dengan cara :

1. Siswa diingatkan kembali dengan materi yang dipelajari pada pertemuan sebelumnya sebelum masuk pada materi baru.

2. Siswa diberikan motivasi dengan mengaitkan manfaat materi yang akan dipelajari dalam kehidupan sehari-hari melalui masalah kontekstual.

3. Siswa diberikan soal latihan secara individu dan dibahas secara bersama-sama di dalam kelas pada setiap akhir pembelajaran.

4. Siswa dibimbing dan dilibatkan dalam menemukan konsep dari pelajaran dengan bantuan LKPD dan alat peraga yang berbeda-beda pada setiap pertemuan.

Berdasarkan tes hasil belajar siswa, terjadi peningkatan nilai rata-rata maupun ketuntasan belajar klasikal dari siklus I hingga siklus III yaitu $60,43(33,33 \%) ; 75,77(66,67 \%)$, dan $85,83(86,67 \%)$.

\section{Saran}

Berdasarkan hasil penelitian tindakan kelas ini, maka peneliti memberikan beberapa saran sebagai berikut.

1. Guru hendaknya memperhatikan kedisiplinan waktu kepada siswa saat kegiatan penemuan dan pengerjaan LKPD dengan diberikan dan diingatkan tentang batas waktu masing-masing untuk setiap tahap dalam pendekatan Pendidikan Matematika Realistik (PMR).

2. Guru hendaknya lebih memberikan perhatian dan bimbingan lebih kepada siswa dengan kemampuan akademis rendah.

3. Guru hendaknya menyusun LKPD berbasis pendekatan Pendidikan Matematika Realistik (PMR) dengan bahasa yang sederhana namun tetap jelas dan terarah.

4. Guru hendaknya menerapkan pendekatan Pendidikan Matematika Realistik (PMR) 
untuk pokok bahasan matematika yang lainnya.

5. Penelitian selanjutnya hendaknya memasukkan dua aktivitas belajar yang tidak dimasukkan pada penelitian ini, yaitu drawing activities dan emotional activities.

\section{DAFTAR PUSTAKA}

Danapriatna, Nana dan Setiawan, Rony. 2005. Pengantar Statistika. Yogyakarta : Graha Ilmu

Daryanto. 2014. Penelitian Tndakan Kelas dan Peneltian Tindakan Sekolah Beserta Contoh-Contohnya. Yogyakarta : Gava Media

Fathurrohman, Muhammad. 2015. ModelModel Pembelajaran Inovatif. Yogyakarta : Ar-Ruzz Media

Gravemeijer, K. P. E. (1994). Developing Realistic Mathematics Education. Utrecht : Freudenthal Institute
Jihad, Asep dan Haris, Abdul. 2012. Evaluasi Pembelajaran. Yogyakarta : Multi Pressindo

Kunandar. 2013. Langkah Mudah Penelitan Tindakan Kelas Sebagai Pengembangan Profesi Guru. Jakarta : Rajawali Pers

Shoimin, Aris. 2014. 68 Model Pembelajaran Inovatif dalam Kurikulum 2013. Yogyakarta : Ar-Ruzz Media

Sudijono, Anas. 2011. Pengantar Evaluasi Pendidikan. Jakarta : Rajawali Pers

Trianto. 2011. Panduan Lengkap Penelitian Tindakan Kelas (Classroom Action Research). Jakarta : Prestasi Pustakaraya

Wijaya, Ariyadi. 2012. Pendidikan Matematika Realistik Suatu Alternatif Pendekatan Pembelajaran Matematika. Yogyakarta : Graha Ilmu 